\title{
Editorial
}

\section{診療を支える枠組み： 最近の動き}

\section{福井次矢}

〔日内会誌 $105 ： 2317 〜 2319 ， 2016 〕$

Key words 医科学的成果，診療を支える枠組み，薬物・医療技術へのアクセス

医療の進歩はまさに日進月歩である。私自 身, 臨床医としての過去 40 年間を振り返って も, 発症後の生存率やQOL（quality of life）一医 療の有効性(アウトカム)一が著しく改善した疾 患を多数目の当たりにしてきた。 内科領域の主 だった疾患に限っても, 胃癌や大腸癌, 心筋梗 塞, 脳梗塞, 関節リウマチ, 白血病, 肺炎など, 枚挙にいとまがなく，このような医療アウトカ ムの著しい改善はほぼ全ての臓器系で起こって きており，しかも，そのペースはますます速ま りつつある。このような著しい改善をもたらし た最大の原因が, 過去約半世紀にわたる医科学 的一特に分子生物学的一アプローチによる様々 な疾患の病態の解明と, それを踏まえた薬物や 治療技術の開発であることに異論を唱える者は いないであろう。

一方，医療現場で多くの患者に新たに開発さ れた薬物や技術が提供されるためには, 医科学 的成果に加えて，そのような成果に関する情報 が多くの医療者に速やかに周知され，さらに
は，新たな知識や技能を備えた医師・医療施設 に患者が心理的, 物理的 (距離), 経済的な障壁 なく速やかにアクセスできる社会体制が整備さ れなくてはならない。これらの点についても， 日本においては，大きな進歩があったといえよ う.1990年代に入って, evidence-based medicine （EBM）の考え方・手順が普及し，2000年頃を 境にEBMの手順に則った診療ガイドラインが数 多く作成されるようになった。 その結果, 新た な医学的知識の日常診療への普及が加速され， 医療内容のばらつきが短期間で縮小化される仕 組みが導入された。また，厚生行政上の様々な 問題は抱えつつも，医療提供体制の整備は着実 に行われてきており，新たに開発された薬物や 医療技術へのアクセスにも工夫が加えられてき ている。その結果, 放置すれば重症化する疾患 への，新たな薬物や技術を用いた早期対応も着 実に可能となってきている.

このような状況に鑑みて, 本号では, 『診療を 支える枠組み：最近の動き』を特集することと 
した. 我々臨床医が最新の医学・医療を遅滞な く多くの患者に提供するプロセスに大きな影響 を与える（あるいは，与える可能性がある）要 因は数多い，それらのうち，私が関わることの 多い8 項目一診療報酬の改定, 費用効果分析, 先進医療制度 - 患者申出療養制度, 医師養成力 リキュラム, 医療の質改善, 日本医療研究開発 機構, ゲノム, 医療事故調査制度一を取り上げ て, 最近の動きについて, それぞれのテーマに 関して中心的役割を果たされている先生方に解 説していただいた.

2 年ごとの診療報酬改定は, 瞬く間に医師の 診療行為を変え, 医療施設の態勢を変えるほど の大きな影響力を有している. マクロとしての 国全体の予算と, ミクロとしての医師や患者一 人ひとりの行動・健康アウトカムを結ぶ重要な 社会機構である.

最近になって, 薬物治療 1 クールに何千万円 もするような新薬が臨床に導入された結果, 適 切な薬剤価格のあり方について, 国をあげての 議論が進行中である. 患者や製薬会社, 国など 様々なステークホルダーによる異なる意見が衝 突しがちであるが，価格決定のプロセスで必ず 考慮すべき要素として, 費用対効果の指標（例 えば，質で調整した期待余命を 1 年延長するた めに必要なコスト) がある.このような指標を 算出する方法が費用効果分析であり, その方法 論と算出された数值の解釈の仕方などに関する 理解が臨床医に求められる時代が到来しつつあ るように思われる。

先進医療制度と患者申出療養はともに, 保険 診療では認められていない最新の医療を保険外 併用療法という枠組みで提供する療養あるいは 臨床試験である. 有効な可能性の高い医療を, その部分だけ患者の自己負担で提供する制度で あり, かつてのような画一的な保険制度だけで は対応が難しい, 様々な要因一医科学的進歩の 速さ，質の高いエビデンスを創出しようとする 臨床研究にかかる時間や費用, 患者の要望, 逼
迫した保険財政など一が反映された制度であ り, 今後の動向が注目される.

医師養成カリキュラムについては, 本年度, 卒前のモデル・コア・カリキュラムの改訂と卒 後臨床研修の到達目標の見直しの作業が同時並 行で行われており, 医師の生涯を通じたキャリ アの目標をつくろうとの機運が高まっている.

最近の10年間で, 質指標QI (quality indicator) を用いた医療の質改善の動きが多くの病院に広 まってきた. 2010年度に始まった厚生労働省に よる「医療の質の評価・公表等推進事業」が全 国に広がる契機になったと考えられるが, 多くの 病院で今後さらなる努力が求められるのが, QI のデータを用いて, いかに現場での改善を実行 するかである. 改善の実行に役立つ様々な考え 方・手順が提唱されており, それらをあらかじめ 知っておくことは, 医療施設の管理面だけでな く, 個別の患者診療面でも役立つはずである.

2015 年度に創設された日本医療研究開発機 構 (Japan Agency for Medical Research and Development : AMED) は, 日本の医療レベルの 向上, 医学研究の発展に決定的に重要な役割を 果たすことになろう。

個人のゲノム情報を用いることで, 個人の体 質や病状に適した効果的・効率的な疾患の診 断, 治療, 予防ができるのではないかと期待さ れている。しかしながら，医師の指示を受けて 行うことが可能な遺伝学的検査の項目は, 欧米 の 4,600 項目に対し, わが国では 144 項目と非 常に少なく, 様々な面でゲノム医療への取り組 みの遅れが指摘されているところである. 医師 をはじめとする多くの医療者がゲノムに関して 学修する機会をどのように提供するのかも, 大 きな課題となっている.

新たな医療事故調査制度が2015年度に開始 されたものの, 届け出が少ないとの批判を受 け, 制度の微調整が必要との議論が行われつつ ある. 誠意をもって医療を提供していても, 事 故につながる個人の要因, 組織の要因をゼロに 
はできない現状を考えると, 当面は医療事故が ゼロになることは至難の業である，医療事故を 繰り返さないための制度への成長が問われると ころである.

診療を支える枠組み一ひいては, 診療内容の 規定にもつながる一は実に複雑であり，一見無 関係とも思われる多くの要因が絡んでいる. 純 粋科学としての生物医学が発展し続けることに
加え, 診療を支える枠組みに関わるテーマが数 えきれないほど存在することは, 医師が一生学 び続けなくてはならない理由の1つでもあり， 成長し続けざるを得ない医師という職業の面白 さでもある.

著者のCOI（conflicts of interest）開示：本論文発表内容 に関連して特に申告なし 